\title{
Mediation Role of Buying Interest in Halal Food Purchase Decisions During the COVID-19 Pandemic
}

\author{
Muhammad Syariful Anam ${ }^{1}$, Arna Asna Annisa ${ }^{1 *}$, and Mohamed Nazeer Mohamed Nafas ${ }^{2}$ \\ ${ }^{1}$ Faculty of Islamic Economics and Business, IAIN Salatiga, Indonesia \\ ${ }^{2}$ Quality Assurance of Halal Accreditation Council (Guarantee) Limited, Sri Lanka
}

\begin{abstract}
The purpose of this study was to determine the mediating role of buying interest in the relationship between knowledge of halal products, halal awareness, and halal labels on decisions to purchase halal food during the COVID-19 pandemic. The data used are primary data obtained through distributing questionnaires to 96 respondents in Sumatera, Java, and Kalimantan island. Data analysis was carried out using the PLS-SEM method. Based on the results of the analysis, the direct influence of product knowledge, halal awareness, and halal labels have no significant effect on purchasing decisions. Meanwhile, buying interest has a positive and significant effect on purchasing decisions. The buying interest variable is significantly and positively influenced by product knowledge, halal awareness, and halal label. Meanwhile, the mediating variable, buying interest, is a significant variable in mediating the effect of product knowledge, halal awareness, and halal labels on halal food purchasing decisions.
\end{abstract}

\section{Introduction}

COVID-19 that hit the world has a serious impact on all aspects. The time it takes for recovery makes the world experience a pandemic. Massive restrictions on public activities during the pandemic caused the economic sector to experience a massive contraction. The impact of all that makes the creative economy fully encouraged as a form of economic recovery policy.

The need for food is absolute to always be met. On the other hand, there are conditions that severely limit community activities. Therefore, the industry in general develops technology in order to survive and at the same time meet consumer needs.

The emergence of the COVID-19 virus, which is thought to be caused by the transmission of wild animals, has made people change their consumption patterns. Coupled with the process of spreading the virus through droplets, making people aware of behavior patterns and the surrounding environment. Therefore, the need for healthy food increases sharply during the pandemic.

* Corresponding author: arnaannisa@iainsalatiga.ac.id 


\section{$A \mathrm{I} \overline{I F B}$ Annual International Conference \\ on Islamic Economics and Business, 2021}

The principle of halal in consumer goods products has standards for health, cleanliness, quality and goodness. Even the halal principle has become a universal value that is used as a guarantee standard for a product (Annisa, 2019; Gillani et al., 2017). Therefore, this study reveals the factors that determine consumers to decide to buy halal products during the pandemic.

\section{Method}

The purpose of this study was to identify the mediating role of buying interest on the factors that influence the decision to purchase halal food during the COVID-19 pandemic. The population in this study is the Muslim millennial generation. Determination of the sample is done by using judgment sampling technique. Meanwhile, the number of samples was determined based on the Cochran formula, and obtained a total sample of 96 respondents spread over the islands of Sumatra, Java and Kalimantan.

This study uses a quantitative approach. The data used are primary data obtained through the distribution of online questionnaires. The questionnaire was assessed using a 5-point Likert scale $(1=$ strongly disagree, to $5=$ strongly agree). Meanwhile, the variables studied include product knowledge, halal awareness, halal label, buying interest, and purchasing decisions, as visualized in Figure 1. Then, data analysis uses the partial least squares method - structural equation modelling (PLS-SEM) with SmartPLS software.

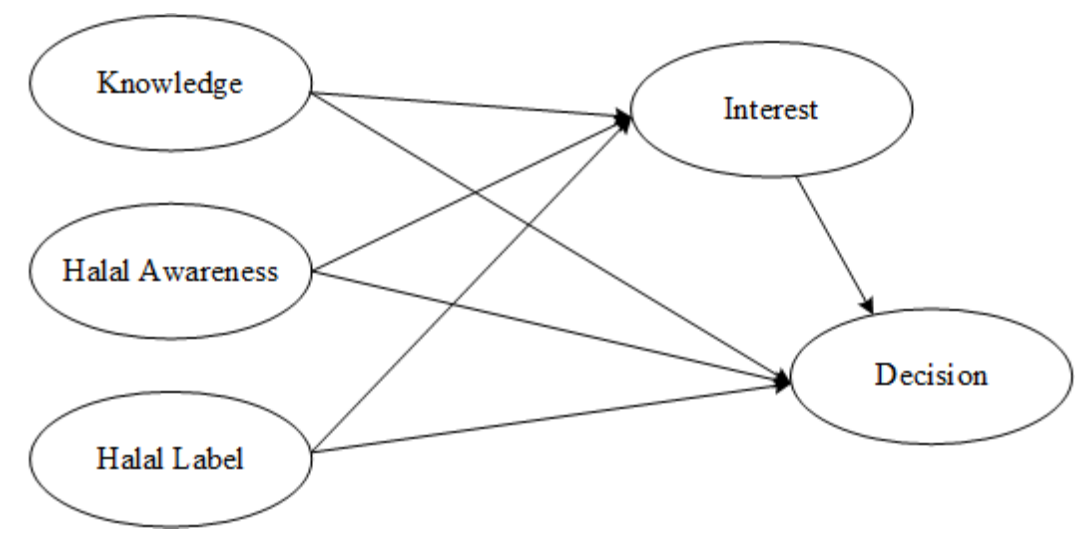

Fig 1. Research Framework

The hypotheses developed in this study are as follows:

H1 : Product knowledge has a significant effect on purchasing decisions.

H2 : Halal awareness has a significant effect on purchasing decisions.

H3 : Halal label has a significant effect on purchasing decisions.

H4 : Purchase intention has a significant effect on purchasing decisions

H5 : Product knowledge has a significant effect on buying interest.

H6 : Halal awareness has a significant effect on buying interest.

H7 : Halal label has a significant effect on buying interest.

H8 : Purchase intention significantly mediates the effect of product knowledge on buying decision.

H9 : Purchase intention significantly mediates the effect of halal awareness on purchasing.

H10 : Purchase intention significantly mediates the effect of halal label on decision purchase. 


\section{AIC $\overline{I E B}$ Annual International Conference \\ on Islamic Economics and Business, 2021}

\section{Result and Discussion}

\subsection{Convergent Validity}

Convergent validity can be seen from the correlation between the indicator scores and the construct scores. The convergent validity requirement that is still accepted is that it has a loading factor value above 0.50 (Ghozali \& Latan, 2015). Based on the results of the analysis (see Figure 2), the factor loading value for the K.02 indicator is below 0.50, so that the indicator is invalid and must be removed. After being removed, the factor loading value of all variables has been above 0.50 , so the model has met the requirements of convergent validity.

In addition to using the factor loading value, convergent validity can also be assessed from the Average Variance Extracted (AVE) score for each construct. Convergent validity requirements can be accepted if the AVE value is 0.50 or higher (Henseler et al., 2016). Based on Table 1, it can be seen that all variables have met the requirements.

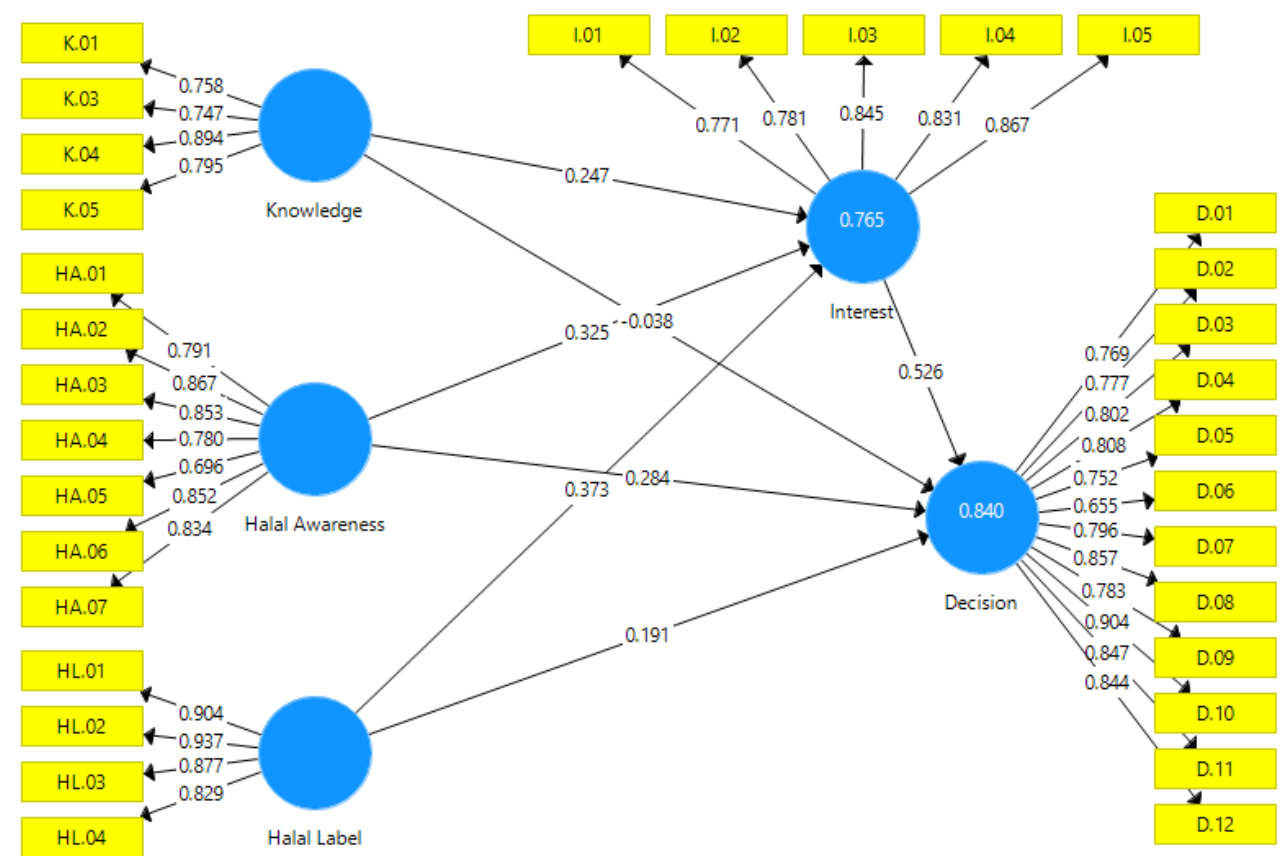

Fig 2. Structural Model Assessment

Table 1. AVE Value

\begin{tabular}{|l|c|c|}
\hline \multicolumn{1}{|c|}{ Variables } & Average Variance Extracted (AVE) & Description \\
\hline Decision & 0.643 & Valid \\
\hline Halal Awareness & 0.660 & Valid \\
\hline Halal Label & 0.787 & Valid \\
\hline Interest & 0.672 & Valid \\
\hline Knowledge & 0.641 & Valid \\
\hline
\end{tabular}




\section{$A \bar{C} \overline{I E B}$ Annual International Conference \\ on Islamic Economics and Business, 2021}

\subsection{Discriminant Validity}

Based on Table 2, the cross loading value has met discriminant validity. This is because the correlation between the latent variable and the indicator is higher than the correlation with the other block latent variables.

Table 2. Cross Loading Value

\begin{tabular}{|c|c|c|c|c|c|}
\hline Indicator & Decision & $\begin{array}{c}\text { Halal } \\
\text { Awareness }\end{array}$ & Halal Label & Interest & Knowledge \\
\hline D.01 & 0.769 & 0.628 & 0.601 & 0.672 & 0.507 \\
\hline D.02 & 0.777 & 0.726 & 0.735 & 0.775 & 0.705 \\
\hline D.03 & 0.802 & 0.659 & 0.583 & 0.678 & 0.597 \\
\hline D.04 & 0.808 & 0.681 & 0.666 & 0.707 & 0.662 \\
\hline D.05 & 0.752 & 0.626 & 0.554 & 0.653 & 0.563 \\
\hline D.06 & 0.655 & 0.529 & 0.536 & 0.541 & 0.437 \\
\hline D.07 & 0.796 & 0.787 & 0.750 & 0.765 & 0.690 \\
\hline D.08 & 0.857 & 0.766 & 0.726 & 0.778 & 0.671 \\
\hline D.09 & 0.783 & 0.606 & 0.703 & 0.675 & 0.506 \\
\hline D.10 & 0.904 & 0.741 & 0.711 & 0.755 & 0.589 \\
\hline D.11 & 0.847 & 0.680 & 0.650 & 0.715 & 0.552 \\
\hline D.12 & 0.844 & 0.722 & 0.672 & 0.795 & 0.550 \\
\hline HA.01 & 0.665 & 0.791 & 0.723 & 0.679 & 0.711 \\
\hline HA.02 & 0.673 & 0.867 & 0.716 & 0.687 & 0.765 \\
\hline HA.03 & 0.700 & 0.853 & 0.762 & 0.730 & 0.774 \\
\hline HA.04 & 0.716 & 0.780 & 0.721 & 0.708 & 0.665 \\
\hline HA.05 & 0.653 & 0.696 & 0.485 & 0.623 & 0.604 \\
\hline HA.06 & 0.758 & 0.852 & 0.633 & 0.727 & 0.661 \\
\hline HA.07 & 0.672 & 0.834 & 0.648 & 0.623 & 0.640 \\
\hline HL.01 & 0.689 & 0.740 & 0.904 & 0.690 & 0.562 \\
\hline HL.02 & 0.775 & 0.761 & 0.937 & 0.712 & 0.575 \\
\hline HL.03 & 0.763 & 0.768 & 0.877 & 0.707 & 0.677 \\
\hline HL.04 & 0.694 & 0.664 & 0.829 & 0.749 & 0.544 \\
\hline I.01 & 0.639 & 0.656 & 0.672 & 0.771 & 0.600 \\
\hline I.02 & 0.694 & 0.700 & 0.629 & 0.781 & 0.647 \\
\hline I.03 & 0.800 & 0.706 & 0.665 & 0.845 & 0.587 \\
\hline I.04 & 0.758 & 0.645 & 0.664 & 0.831 & 0.653 \\
\hline I.05 & 0.749 & 0.747 & 0.675 & 0.867 & 0.674 \\
\hline K.01 & 0.596 & 0.626 & 0.465 & 0.582 & 0.758 \\
\hline K.03 & 0.566 & 0.648 & 0.530 & 0.615 & 0.747 \\
\hline K.04 & 0.602 & 0.733 & 0.569 & 0.668 & 0.894 \\
\hline K.05 & 0.591 & 0.708 & 0.563 & 0.600 & 0.795 \\
\hline & & & & & \\
\hline
\end{tabular}

\subsection{Reliability}

Table 3 is the result of construct reliability test as measured by Cronbach's alpha and composite reliability. The construct can be declared reliable if the value of Cronbach's alpha and composite reliability is above 0.70 (Ghozali \& Latan, 2015). Based on Table 3, the value of Cronbach's alpha and composite reliability for all variables is above 0.70 , so it can be concluded that the construct has very good reliability. 


\section{$A \mathrm{I} \overline{I E B}$ Annual International Conference \\ on Islamic Economics and Business, 2021}

Table 3. Cronbach's Alpha and Composite Reliability

\begin{tabular}{|l|c|c|c|}
\hline \multicolumn{1}{|c|}{ Variables } & Cronbach's Alpha & Composite Reliability & Description \\
\hline Decision & 0.949 & 0.955 & Reliable \\
\hline Halal Awareness & 0.913 & 0.931 & Reliable \\
\hline Halal Label & 0.909 & 0.937 & Reliable \\
\hline Interest & 0.877 & 0.911 & Reliable \\
\hline Knowledge & 0.811 & 0.877 & Reliable \\
\hline
\end{tabular}

\subsection{Determination Coefficient}

Based on Table 4, the buying interest variable has an R-Square value of 0.765 . That is, buying interest can be explained by knowledge of halal products, halal awareness, and halal labels by 76.5 percent, while 23.5 percent is explained by other variables outside the model. Furthermore, the R-Square value of the purchasing decision variable is 0.840 . This means that purchasing decisions can be explained by knowledge of halal products, halal awareness, halal labels, and buying interest by 84 percent, while 16 percent is influenced by other variables outside the model.

Table 4. R Square Value

\begin{tabular}{|l|c|c|}
\hline \multicolumn{1}{|c|}{ Variable } & R Square & R Square Adjusted \\
\hline Interest & 0.765 & 0,757 \\
\hline Decision & 0.840 & 0.833 \\
\hline
\end{tabular}

\subsection{Path Coefficient}

The results of data analysis are presented in Table 5, the hypothesis can be accepted if the pvalue $<0.05$. As can be seen, $\mathrm{H} 1, \mathrm{H} 2$, and $\mathrm{H} 3$ are not significant to the purchase decision because the p-value is greater than 0.05 . Meanwhile, $\mathrm{H} 4$ has a positive and significant relationship with purchasing decisions. Meanwhile, H5, H6, and $\mathrm{H} 7$ were found to have a positive and significant effect on buying interest. In addition, $\mathrm{H} 8, \mathrm{H} 9$, and $\mathrm{H} 10$ positively and significantly mediate the effect of product knowledge, halal awareness, halal label on purchasing decisions of halal food.

Table 5. Path Coefficient

\begin{tabular}{|c|c|c|c|c|c|}
\hline Hypothesis & Relationship & $\begin{array}{c}\text { Original } \\
\text { Sample }\end{array}$ & $\begin{array}{c}\text { Standard } \\
\text { Deviation }\end{array}$ & t-value & p-value \\
\hline $\mathrm{H} 1$ & $\mathrm{~K} \rightarrow \mathrm{D}$ & -0.038 & 0.116 & 0.329 & 0.724 \\
\hline $\mathrm{H} 2$ & $\mathrm{HA} \rightarrow \mathrm{D}$ & 0.284 & 0.180 & 1.574 & 0.116 \\
\hline $\mathrm{H} 3$ & $\mathrm{HL} \rightarrow \mathrm{D}$ & 0.191 & 0.128 & 1.489 & 0.137 \\
\hline $\mathrm{H} 4$ & $\mathrm{I} \rightarrow \mathrm{D}$ & 0.526 & 0.092 & 5.725 & 0.000 \\
\hline $\mathrm{H} 5$ & $\mathrm{~K} \rightarrow \mathrm{I}$ & 0.247 & 0.081 & 3.061 & 0.002 \\
\hline $\mathrm{H} 6$ & $\mathrm{HA} \rightarrow \mathrm{I}$ & 0.325 & 0.123 & 2.635 & 0.009 \\
\hline $\mathrm{H} 7$ & $\mathrm{HL} \rightarrow \mathrm{I}$ & 0.373 & 0.095 & 3.920 & 0.000 \\
\hline $\mathrm{H} 8$ & $\mathrm{~K} \rightarrow \mathrm{I} \rightarrow \mathrm{D}$ & 0.130 & 0.046 & 2.853 & 0.005 \\
\hline $\mathrm{H} 9$ & $\mathrm{HA} \rightarrow \mathrm{I} \rightarrow \mathrm{D}$ & 0.171 & 0.082 & 2.071 & 0.039 \\
\hline $\mathrm{H} 10$ & $\mathrm{HL} \rightarrow \mathrm{I} \rightarrow \mathrm{D}$ & 0.196 & 0.052 & 3.763 & 0.000 \\
\hline
\end{tabular}

\subsection{Predictive Relevance $\left(Q^{2}\right)$}

This analysis was conducted using the blindfolding method to determine whether the variables used in the research model have predictive relevance. The requirement that must be 


\section{$A I \overline{C F B} \quad$ Annual International Conference \\ on Islamic Economics and Business, 2021}

met is that the value of Q2 must be greater than 0 so that the model can be said to have predictive relevance (Ghozali \& Latan, 2015). Based on Table 6, these requirements have been met.

Table 6. $Q^{2}$ Value

\begin{tabular}{|l|c|c|}
\hline & $\mathbf{Q}^{\mathbf{2}}(\mathbf{= 1 - S S E} / \mathbf{S S O})$ & Description \\
\hline Interest & 0.462 & Predictive \\
\hline Decision & 0.465 & Predictive \\
\hline
\end{tabular}

\subsection{Model Fit}

The measure used to evaluate the fit model is the Standardized Root Mean Square Residual (SRMR) and the Normed Fit Index (NFI). The condition for the model to be suitable is the SRMR value $<0.10$, whereas if the NFI value is closer to 1 , it means the model is getting better (Hu \& Bentler, 1999). Based on Table 7, the SRMR value is $0.068(<0.10)$, then the model can be said to be fit, while the NFI value is 0.658 which indicates the model is getting better. Therefore, it can be concluded that the structural model is considered suitable or fit and is quite good.

Table 7. Model Fit

\begin{tabular}{|l|c|c|}
\hline & Saturated Model & Estimated Model \\
\hline SRMR & 0.068 & 0.068 \\
\hline NFI & 0.658 & 0.658 \\
\hline
\end{tabular}

\subsection{Discussion}

Based on the results of the analysis, the direct relationship of the three independent variables to the decision to purchase halal food obtained insignificant results. The variable is product knowledge on purchasing decisions whose results are not significant and are supported by previous research from Bian \& Moutinho (2011) and Putri et al. (2019), halal awareness which also validates previous research from Awan et al. (2015) and Vanany et al. (2019) which also found a direct relationship of halal awareness to purchase decisions whose results were not significant, and the direct influence of halal labels on purchasing decisions which obtained insignificant results and was supported by research from Fadila et al. (2020). However, buying interest has positive and significant results on purchasing decisions, and supports previous research conducted by Bashir (2019) and Vizano et al. (2021).

Meanwhile, the influence of the three independent variables on buying interest all obtained positive and significant results. Where, product knowledge can positively and significantly affect buying interest, so this result validates the research of Sriminarti \& Nora (2018) and Nurhayati \& Hendar (2020). Halal awareness was also identified as having a positive and significant relationship with buying interest, this finding supports previous research conducted by Nurhayati \& Hendar (2020) and Najmudin et al. (2021). In addition, the results of data analysis that have been carried out show that halal labels have a positive and significant relationship with purchase intention, and support the findings of Astuti \& Asih (2021).

As can be seen in Table 5, it can be concluded that if the variables of product knowledge, halal awareness, and halal label are mediated by buying interest, the results will be significant, because in a direct relationship the three variables obtain insignificant results. The conclusion of the mediating role of the buying interest variable in this study is that it has a full mediation role. This shows that the importance of forming buying interest in advance 


\section{$A I C \overline{I E B} \quad$ Annual International Conference \\ on Islamic Economics and Business, 2021}

so that product knowledge, halal awareness, and halal labels can influence the decision to purchase halal food.

\section{Conclusion}

Based on the results of the research and discussion above, it shows that for a direct influence, both knowledge of halal products, halal awareness, and halal labels do not significantly influence the decision to buy halal food during the COVID-19 pandemic. However, through the mediating role of buying interest, all variables have a significant effect on purchasing decisions. This means that before consumers make a decision, it is important for them to cultivate interest first, so that if they feel confident about halal food, it will be easier to make a decision.

The findings of this study provide useful recommendations for halal food manufacturers. It is important for producers to design in such a way about halal food campaigns so that they can influence consumers' personal perceptions and religious beliefs. Manufacturers must also realize that consumers have knowledge and will evaluate products before buying them, so they need to pay attention to the quality and health value of the food they sell, especially during the COVID-19 pandemic, consumers tend to choose healthy foods. In addition, it is also recommended for producers to add halal labels/logos to their food products so that Muslim consumers can buy them, and aims to increase sales and consumers.

For related parties such as MUI, religious institutions, and scholars to carry out da'wah more massively with the aim of increasing religion and public awareness of the importance of halal products. In addition, MUI is also expected to continue to socialize and promote related to halal certification. Thus, the hope to be achieved is that people are increasingly aware of the importance of halal products, which in turn will develop their interest in making decisions to purchase halal products.

However, there are some limitations in this study. First, the sample used is still too small. Thus, further research is expected to use a larger number of samples so that the results obtained can be generalized. Second, the moderating or mediating effect of certain variables such as attitudes, religiosity, and halal perception can be explored in future research using a structural equation model.

\section{References}

Annisa, A. A. (2019). Kopontren dan Ekosistem Halal Value Chain. Jurnal Ilmiah Ekonomi Islam, 5(01), 1-8. https://doi.org/10.29040/jiei.v5i01.398

Astuti, Y., \& Asih, D. (2021). Country of Origin, Religiosity and Halal Awareness: A Case Study of Purchase Intention of Korean Food. Journal of Asian Finance, Economics and Business, 8(4), 413-421. https://doi.org/10.13106/jafeb.2021.vol8.no4.0413

Awan, H. M., Siddiquei, A. N., \& Haider, Z. (2015). Factors affecting Halal purchase intention - evidence from Pakistan's Halal food sector. Management Research Review, 38(6), 640-660. https://doi.org/10.1108/MRR-01-2014-0022

Bashir, A. M. (2019). Effect of halal awareness, halal logo and attitude on foreign consumers' purchase intention. British Food Journal, 121(9), 1998-2015. https://doi.org/10.1108/BFJ-01-2019-0011

Bian, X., \& Moutinho, L. (2011). The role of brand image, product involvement, and knowledge in explaining consumer purchase behaviour of counterfeits: Direct and indirect effects. European Journal of Marketing, 45(1), 191-216. https://doi.org/10.1108/03090561111095658

Fadila, C. T., Farlian, T., \& Ramly, A. (2020). The Influence of Halal Label, Product Quality, 


\section{$A \mathrm{C} \overline{I F B}$ Annual International Conference \\ on Islamic Economics and Business, 2021}

and Price on Purchasing Decisions. Journal of Finance and Islamic Banking, 3(1), 95113. https://doi.org/10.22515/jfib.v3i1.2627

Ghozali, I., \& Latan, H. (2015). Partial Least Squares: Konsep, Teknik dan Aplikasi Menggunakan Program SmartPLS 3.0 (2nd ed.). Badan Penerbit-Undip.

Gillani, S. H. B., Khan, M. M. S., \& Ijaz, F. (2017). Factors Reinforcing Pakistan Halal Food Industry to be the World Halal Food Hub. Journal of Education and Social Sciences, 6.

https://www.researchgate.net/publication/316324085_FACTORS_REINFORCING

PAKISTAN_HALAL_FOOD_INDUSTRY_TO_BE_THE_WORLD_HALAL_FOO D HUB

Henseler, J., Hubona, G., \& Ray, P. A. (2016). Using PLS path modeling in new technology research: Updated guidelines. Industrial Management and Data Systems, 116(1), 2-20. https://doi.org/10.1108/IMDS-09-2015-0382

Hu, L., \& Bentler, P. M. (1999). Cutoff criteria for fit indexes in covariance structure analysis: Conventional criteria versus new alternatives. Structural Equation Modeling: A Multidisciplinary Journal, 6(1), 1-55. https://doi.org/10.1080/10705519909540118

Najmudin, N., Syihabudin, S., \& Fatoni, A. (2021). The Effect of Halal Awareness and Food Ingredients on Consumer Interests of Culinary Seafood Beach Tourism. Islamiconomic: Jurnal Ekonomi Islam, 12(1), 23-38. https://doi.org/10.32678/ijei.v12i1.273

Nurhayati, T., \& Hendar, H. (2020). Personal intrinsic religiosity and product knowledge on halal product purchase intention: Role of halal product awareness. Journal of Islamic Marketing, 11(3), 603-620. https://doi.org/10.1108/JIMA-11-2018-0220

Putri, I. S., Daryanti, S., \& Ningtias, A. R. (2019). The Influence of Knowledge and Religiosity with Mediation of Attitude Toward the Intention of Repurchasing Halal Cosmetics. 12th International Conference on Business and Management Research (ICBMR 2018), 72, 172-177.

Sriminarti, N., \& Nora, L. (2018). The Role of Product Knowledge and Attitudes toward Purchasing Intentions: The Moderating Effect of Religiosity on Halal Cosmetics. KnE Social Sciences, 3(10), 518-529. https://doi.org/10.18502/kss.v3i10.3153

Vanany, I., Soon, J. M., Maryani, A., \& Wibawa, B. M. (2019). Determinants of halal-food consumption in Indonesia. Journal of Islamic Marketing, 11(2), 507-521. https://doi.org/10.1108/JIMA-09-2018-0177

Vizano, N. A., Khamaludin, K., \& Fahlevi, M. (2021). The Effect of Halal Awareness on Purchase Intention of Halal Food: A Case Study in Indonesia. Journal of Asian Finance, Economics and Business, 8(4), 441-453. https://doi.org/10.13106/jafeb.2021.vol8.no4.0441 